\title{
Impact of Fibroblast Growth Factor-Binding Protein-1 Expression on Angiogenesis and Wound Healing
}

\author{
Elena Tassi, Kevin McDonnell, Krissa A. Gibby, \\ Jason U. Tilan, Sung E. Kim, David P. Kodack, \\ Marcel O. Schmidt, Ghada M. Sharif, \\ Christopher S. Wilcox, William J. Welch, \\ G. Ian Gallicano, Michael D. Johnson, \\ Anna T. Riegel, and Anton Wellstein \\ From the Lombardi Cancer Center, Georgetown University, \\ Washington, DC
}

Fibroblast growth factors (FGFs) participate in embryonic development, in maintenance of tissue homeostasis in the adult, and in various diseases. FGF-binding proteins (FGFBP) are secreted proteins that chaperone FGFs stored in the extracellular matrix to their receptor, and can thus modulate FGF signaling. FGFBP1 (alias BP1, FGF-BP1, or HBp17) expression is required for embryonic survival, can modulate FGF-dependent vascular permeability in embryos, and is an angiogenic switch in human cancers. To determine the function of BP1 in vivo, we generated tetracycline-regulated conditional BP1 transgenic mice. BP1-expressing adult mice are viable, fertile, and phenotypically indistinguishable from their littermates. Induction of BP1 expression increased mouse primary fibroblast motility in vitro, increased angiogenic sprouting into subcutaneous matrigel plugs in animals and accelerated the healing of excisional skin wounds. FGF-receptor kinase inhibitors blocked these effects. Healing skin wounds showed increased macrophage invasion as well as cell proliferation after BP1 expression. Also, BP1 expression increased angiogenesis during the healing of skin wounds as well as after ischemic injury to hindlimb skeletal muscles. We conclude that BP1 can enhance FGF effects that are required for the healing and repair of injured tissues in adult animals. (Am J Pathol 2011, 179:2220-2232; DOI: 10.1016/j.ajpath.2011.07.043)

The family of fibroblast growth factors (FGFs) encompasses 18 distinct FGF receptor ligands, with a wide expression range and a significant role in angiogenesis, tumor progression, wound healing, and embryonic development. ${ }^{1-4}$ Many members of the FGF family, such as FGF1 and FGF2, are immobilized in the extracellular matrix (ECM) bound to heparan sulfate proteoglycans (HSPGs) and released from this storage site by proteases and heparanases. ${ }^{4-6}$ The involvement of carrier proteins that shuttle FGFs from their storage site to their receptors represents an alternative mode of regulation of FGF release from the ECM. ${ }^{1,7}$

FGF-binding protein 1 (BP1, FGFBP1, FGF-BP1, or $\mathrm{HBp} 17),{ }^{8}$ the best characterized of the three known secreted FGFBPs, ${ }^{9}$ is an extracellular chaperone that binds FGF1, 2, 7, 10, and 22 in a reversible, noncovalent manner. ${ }^{8,10-12}$ Binding of the $\mathrm{C}$-terminus of the BP1 protein is sufficient for its interaction with FGF2. ${ }^{13}$ After binding to $\mathrm{BP} 1$, the biochemical and biological activities of FGF are positively modulated. ${ }^{14}$ Several findings from different laboratories indicate that BP1 can contribute to embryonic development, ${ }^{15}$ angiogenesis, tumor growth, and malignant progression, ${ }^{11,12,14-20}$ as well as the maintenance and reinnervation of the neuromuscular junction. ${ }^{21}$ We reported earlier that expression of BP1 in SW13 cells induces FGF2 release from the cells, FGF-dependent colony formation in soft agar, and the growth of highly vascularized tumors in nude mice. ${ }^{11}$ In contrast, depletion of endogenous BP1 from ME180 cells was observed to reduce the release of ECM bound FGF2 into the cell supernatants and to increase FGF2 immobilized on the cell surface.$^{16}$ Consistent with a role in tumor angiogenesis, we found that addition of BP1 protein can increase blood vessel growth in a chicken chorioallantoic membrane (CAM) assay. ${ }^{14}$ In a BP1 transgenic chicken model, early embryonic death occurs due to vascular leakage, hemorrhage, and increased FGF bioavailability. ${ }^{15}$ Moreover, we described BP1 as a rate-limiting factor for

Supported in part by NIH grant RO1 CA71508 (A.W.) and PO1 HL068686 (C.S.W., W.J.W., and A.W.), and by the Lombardi Cancer Center Shared Resources grant P30 CA51008.

Accepted for publication July 13, 2011

Supplemental material for this article can be found at http://ajp. amjpathol.org or at doi: 10.1016/j.ajpath.2011.07.043.

CME Disclosure: None of the authors disclosed any relevant financial relationships.

Address reprint requests to Anton Wellstein M.D., Ph.D., Georgetown University, Lombardi Cancer Center, 3970 Reservoir Rd., NW, Washington, DC 20057. E-mail: wellstea@georgetown.edu. 
angiogenesis-dependent tumor growth of human squamous cell carcinoma and colon adenocarcinoma cell lines, ${ }^{16}$ and found BP1 protein and mRNA upregulated in colon and pancreatic cancer archival tissue samples ${ }^{19}$ as well as in incisional skin wounds in a chimeric SCID mouse/human xenograft model. ${ }^{17}$ On the other hand, recent studies in amyotrophic lateral sclerosis (ALS) linked down-regulation of BP1 to progression of this neuromuscular disease. In particular, the maintenance of innervation of neuromuscular junctions is controlled by FGF activity, and BP1 enhancement of FGF activity is thought to be crucial for repair of the junctions. ${ }^{21,22}$

Wound healing is a complex, multistep process that consists of an inflammatory, proliferative and maturation phase ${ }^{23}$ and requires the action of several growth factors and cytokines, including FGFs such as FGF2, 7, 10, and 22. ${ }^{24,25} \mathrm{FGF} 1,2$, and 7 mRNAs are also upregulated in wounded skin. ${ }^{26}$ Despite FGF signal redundancy, FGF2 appears to have a crucial role during wound healing and $\mathrm{FGF}^{-1-}$ mice display delayed wound healing, ${ }^{27}$ in contrast to FGF1 and FGF7 knockout mice. ${ }^{28,29}$ In addition, blocking antibodies to FGF2 inhibit wound healing in rats. ${ }^{30}$ Commensurate with these results, several in vitro studies have characterized FGF2 as a chemotactic, mitogenic and pro-angiogenic factor for fibroblasts and endothelial cells, as reviewed elsewhere, ${ }^{31-33}$ further suggesting its contribution in the different phases of wound healing.

As discussed above, BP1 has been shown to interact with FGF2, 7, 10, and 22, ${ }^{8,10-12}$ which are involved in skin wound healing. Here we report on the phenotype of a transgenic mouse model with conditional expression of BP1. ${ }^{34,35}$ We found that induction of BP1 transgene expression increases primary mouse fibroblast motility in vitro, and angiogenesis in subcutaneous Matrigel plugs in vivo. Moreover, we show that the conditional expression of BP1 elicits an accelerated angiogenic response and tissue repair in healthy adult animals with full-thickness excisional skin wounds or ischemic muscle injury.

\section{Materials and Methods}

\section{Generation of Transgenic Mice}

A 1.7-kb DNA fragment was excised with Pmll restriction enzyme from pUHC13-3/BP expression vector ${ }^{36}$ and was used to generate transgenic mice by pronuclear injection of the constructs shown in Supplemental Figure S1 (available at $h$ ttp://ajp.amjpathol.org). Genotyping by real-time PCR identified founders (TRE-BP1), which were mated with mice expressing the tetracycline transactivator (tTA) under the control of a CMV promoter (CMV- tTA; Jackson Laboratories, Bar Harbor, ME). Double-transgenic animals (tTA/TRE-BP1) are named BP1. BP1 transgene expression was silenced by feeding a diet supplemented with an orally available tetracycline (ie, doxycycline) from Bio-Serv (Frenchtown, NJ) (BP1 OFF) and induced by a switch to regular mouse chow that lacks tetracycline (BP1 $\mathrm{ON}$ ) typically for 2 weeks before the experiments. Five lines were established successfully and, of these, three were used for experimental procedures. Because of the embryonic lethality of BP1 transgene expression ${ }^{37}$ (see Introduction), animals were mated while being fed a tetracycline-containing diet. Transgenic and nontransgenic littermates showed no toxic effect of the diet. On conditional expression of the BP1 transgene using a tetracycline-free diet for up to 12 months after birth, BP1 mice were viable and did not show gross phenotypic alterations or microscopic alterations by a complete necropsy analysis of animals. Animal experiments were reviewed and approved by the Institutional Animal Care and Use Committee.

\section{Real-Time PCR}

Genomic mouse DNA was extracted from the tips of mouse tails with the aid of Dnaesy Tissue Kit (Qiagen, Valencia, CA). Real-time PCR for TRE-BP1 and tTA was performed in an iCycler iQ (Bio-Rad Laboratories, Hercules, CA) using the iQ SYBR Green Supermix (Bio-Rad Laboratories) under the following conditions: $95^{\circ} \mathrm{C}$ for 3 minutes, followed by 40 cycles $\left(95^{\circ} \mathrm{C}\right.$ for 20 seconds, $55^{\circ} \mathrm{C}$ for 30 seconds, and $72^{\circ} \mathrm{C}$ for 40 seconds). Total RNA was isolated from transgenic mouse skin using RNeasy Fibrous Tissue Kit (Qiagen) and from cultured cells using RNA STAT-60 (Tel-Test, Friendswood, TX), respectively, according to the manufacturer's instructions. cDNA was synthesized with the iScript cDNA Synthesis Kit, according to the manufacturer's protocol (BioRad Laboratories). Real-time PCR for BP1 and mouse $\beta$-actin or glyceraldehyde 3-phosphate dehydrogenase (GADPH) quantification was performed with the aid of the iQ SYBR Green Supermix (Bio-Rad Laboratories) under the protocol described above. The following PCR primers were used: TRE-BP1 sense 5'-ATGAAGATCTGTAGCCTCACC-3' and antisense 5'-TTCTGAGACCACTTTGCTGT-3'; tTA sense 5'-CGACAAGCTATCGAATTATTTGAT-3' and antisense 5'-GCGGACCCACTTTCACAT-3'; mouse $\beta$-actin sense $5^{\prime}$-GGCGCTTTTGACTCAGGATTTAA-3' and antisense 5'-CCTCAGCCACATTTGTAGAACTTT-3'; and mouse GADPH sense 5'-TGCACCACCAACTGCTTA-3' and antisense 5'-GGATGCAGGGATGATGTTC-3'.

\section{Western Blots and Immunoprecipitation}

Immunoprecipitation and Western blot analyses for human BP1 were performed as described earlier. ${ }^{19}$ Briefly, small intestines from BP1 OFF and BP1 ON mice were homogenized in $1 \mathrm{~mL}$ of lysis buffer with a MagNa lyser homogenizer (Roche, Indianapolis, IN) and BP1 immunoprecipitated with $2 \mu \mathrm{g}$ of $3 \mathrm{E} 11$ mouse monoclonal antibody ${ }^{19}$ for 2 hours at $4^{\circ} \mathrm{C}$. Immunoblot analyses were performed with a rabbit polyclonal antibody to human FGFBP1 (Sigma, St. Louis, MO) and with a mouse monoclonal antibody to mouse actin (Millipore, Temecula, CA) according to the manufacturers' instructions. Human recombinant FGFBP1 (20 ng; R\&D Systems, Minneapolis, $\mathrm{MN}$ ) was used as a positive control. 


\section{Culture of Mouse Primary Fibroblasts}

Primary fibroblast cultures were grown from minced tissue fragments of BP1 transgenic mouse abdominal wall and cultured in Dulbecco's modified Eagle's medium (DMEM; Invitrogen, Carlsbad, CA) supplemented with $20 \%$ fetal bovine serum (FBS), $100 \mathrm{U} / \mathrm{mL}$ of penicillin and streptomycin, and $2 \mathrm{mmol} / \mathrm{L}$ of L-glutamine (Invitrogen). Cells were maintained in the same culture media and passaged at a 1:3 ratio.

\section{Mouse Primary Fibroblast Proliferation Assay}

Mouse primary fibroblasts (MPFs) were seeded in three replicates in 96-well plates in DMEM supplemented with $10 \%$ FBS. After 24 hours, the proliferation rate was evaluated by the addition of $10 \mu \mathrm{l} /$ well of WST-1 reagent, as suggested by the manufacturer (Roche).

\section{Detection of BP1 Protein in MPF Supernatants}

BP1 protein was isolated by heparin-sepharose affinity of $100 \mathrm{~mL}$ of serum-free conditioned media harvested from MPFs that were induced or not induced for BP1 expression by growth in the absence or presence of tetracycline. After a wash with $0.3 \mathrm{~mol} / \mathrm{L} \mathrm{NaCl}, \mathrm{BP} 1$ protein was eluted in three $1-\mathrm{mL}$ aliquots of $0.9 \mathrm{~mol} / \mathrm{L} \mathrm{NaCl}$ elution buffer as described previously. ${ }^{11}$ BP1 in the fractions was detected by Western blot analysis with the anti-BP1 3E11 monoclonal antibody (mAb) and by direct enzyme-linked immunosorbent assay, as previously described. ${ }^{19}$ MPFs grown on coverslips were stained by immunofluorescence with the anti-BP1 mAb $3 \mathrm{E} 11$ as described previously. ${ }^{19}$

\section{Cell Migration Assay}

\section{Time-Lapse Imaging}

Cell culture inserts to generate $0.5-\mathrm{mm}$-diameter, rectangular cell free spaces (Ibidi $\mathrm{GmbH}$, Martinsried, Germany) were placed into 24-well plates. MPFs were plated in the open space in 10\% FBS-containing DMEM in the presence or absence of doxycycline (1 $\mu \mathrm{g} / \mathrm{mL}$; Sigma) (BP1 OFF and BP1 ON, respectively 20,000 cells/well) and allowed to attach overnight. After removing the inserts, the wells were filled with complete growth media in the presence or absence of PD173074 (100 nmol/L; Calbiochem, Gibbstown, NJ) or FGF2 (100 ng/mL; Invitrogen) alone or in combination. All experiments were performed in the presence of mitomycin C ( $5 \mu \mathrm{g} / \mathrm{mL}$; Sigma) to inhibit cell proliferation. Motorized, time-lapse phase contrast microscopy (Nikon Eclipse TE-300 inverted microscope system, Melville, NY) was used to continuously capture images (triplicate wells per condition, two images per well, 15 minutes intervals). Migration was determined by measuring the cell-free area in the gap at different time points using ImageJ software from the $\mathrm{Na}$ tional Institutes of Health (http://rsb.info.nih.gov/ij).

\section{Electric Impedance Sensing}

Cells are grown on microelectrodes embedded into the bottom of culture dishes and the impedance of the cell monolayer is measured in real-time as described elsewhere. ${ }^{38,39}$ Here, MPFs were plated into wells of an $x$ Celligence E-culture plate array (Roche, Indianapolis, IN) and followed until they reached confluence and steady-state impedance. Monolayers were then disrupted by scratching with a sterile pipette tip. The impedance of the cell monolayer before and after scratching as well as the recovery of full impedance was monitored in real time on an xCelligence Instrument (Roche) and indicates the closure of the monolayer.

\section{Matrigel Angiogenesis Assay}

Growth factor-depleted Matrigel (0.5 mL; BD Biosciences, Franklin Lakes, NJ) was injected subcutaneously into mice. Four days later, the Matrigel plugs were harvested, and $5-\mu \mathrm{m}$ sections of formalin-fixed, paraffin-embedded tissues were stained with H\&E. The relative area of each Matrigel plug penetrated by microvessels was measured, endothelial cell nuclei counted in 10 random fields and the angiogenesis index determined as the product of endothelial cell number and the fraction of the plug penetrated. PD173074 (Calbiochem) was administered by intraperitoneal injection at $1 \mathrm{mg} / \mathrm{kg} /$ day. Mice were pretreated for 2 days before the Matrigel injection and continued to be treated daily for an additional 4 days.

\section{Wound Healing Assay}

A dermal biopsy punch (3 mm diameter; Miltex Inc., Bethpage, NY) was used to create four, full-thickness skin wounds made through the skin and panniculus carnosus muscle in anesthetized 4-month-old male mice. After wounding, groups of mice were euthanized at daily intervals and wounded tissues harvested. Histological sections were cut at a right angle to the skin surface across the wound. Serial paraffin-embedded tissue sections (5 $\mu \mathrm{m})$ were stained with hematoxylin and eosin (H\&E) and analyzed by serial sectioning as described in Ref. ${ }^{40}$ The percentage of re-epithelialization was calculated with the following formula: $100 \times\{[$ (wound diameter $)-$ (epidermal gap) $] /($ wound diameter)\}, where the epidermal gap is the distance between opposite epithelial tongues. The number of capillaries, infiltrating cells (macrophages and fibroblasts), and the re-epithelialization were measured by two observers blinded to the design. Photographs of open wound areas at different times after injury were used to analyze wound closure that was quantified using ImageJ software (http://rsb.info.nih.gov/ij).

\section{Immunohistochemistry}

Immunohistochemical analyses using antibodies to human BP1 (Sigma), CD31 (Becton Dickinson), F4/80 (AbD Serotec, Raleigh, NC), $\alpha$-smooth muscle actin ( $\alpha \mathrm{SMA}$ ) (Sigma), and PCNA (Sigma) were performed according to the manufacturer's instructions. CD31-positive capil- 
laries and $\mathrm{F} 4 / 80$ positive macrophages ${ }^{41}$ were counted in four nonoverlapping visual fields. The proliferation index of cells in the granulation tissues was scored as PCNApositive nuclei per 100 cells in five to 10 nonoverlapping visual fields.

\section{Mouse Hindlimb Ischemia Model}

Animals were anesthetized with Avertin $(250 \mathrm{mg} / \mathrm{kg})$ intraperitoneally, followed by hair removal from the hindlimb. The femoral artery was exposed aseptically through a 2-mm incision and isolated from the femoral vein and nerve. The femoral artery was ligated with a 6-0 suture just proximal to the bifurcation of the superficial and deep femoral arteries. Muscles were harvested 30 days after ligation and frozen sections $(5 \mu \mathrm{m})$ processed for immunostaining. Vascularization in the injured adductor muscle was measured using CD31+ vessels as a marker of capillary angiogenesis, with data represented as the average capillaries per muscle fiber in 5 random fields of view.

\section{Statistical Analyses}

Prism 5 (GraphPad) software was used to compare the means of two or more groups by Student's t-test or analysis of variance, respectively. Times to $50 \%$ wound closure in vivo were compared by Kaplan-Meier analysis. Angiogenesis and cell infiltration scores in healing wounds were analyzed by $\chi^{2}$ test for trend. Statistical significance was defined as $P<0.05$.

\section{Results}

\section{Conditional Expression of BP1 in Transgenic Animals}

For conditional BP1 expression, we generated mice that expressed the BP1 transgene under the control of tetracycline using the tet-off system ${ }^{34,42,43}$ (see Supplemental Figure S1A at $h t t p: / / a j p . a m j p a t h o l . o r g)$. We found a threefold induction of BP1 mRNA in mouse skin (Figure 1A) and small intestines (see Supplemental Figure S1C at http://ajp.amjpathol.org) when adult animals were switched to a diet without tetracycline. This BP1 mRNA induction is within or below the range observed when comparing premalignant or cancerous lesions with the respective control tissues. ${ }^{11,19,44} \mathrm{BP} 1$ protein expression in different tissues was compared between animals that were induced or not induced for expression of the transgene. Immunohistochemistry of the mouse skin showed a strong BP1 protein expression in the epidermis and hair follicles of animals induced for BP1 expression relative to the noninduced animals (Figure $1 \mathrm{C}$ ), with a lesser expression in the dermis (Figure 1C, arrowheads). Likewise, analysis of BP1 transgene expression in organs of the mouse gastrointestinal and respiratory tract (tongue, trachea, esophagus, and small intestine) resulted in a distinct protein expression after transgene induction (see Supplemental Figure S1B at http://ajp.amjpathol.org). Human ME180 cells that express endogenous BP1 and the BP1 negative SW13 cell line ${ }^{11}$ were subjected to the same fixation and staining process and served as a positive and negative control respectively (Figure 1C, bottom panel). Immunoprecipitation followed by Western blots of small intestine tissue extracts showed induction of BP1 protein expression (see Supplemental Figure S1D at http://ajp.amjpathol.org).

\section{Conditional Expression of BP1 in MPFs}

Regulation of BP1 transgene espression by tetracycline was also investigated in primary fibroblast cultures derived from the transgenic mice. A 12-fold upregulation of BP1 mRNA was detected in MPFs when compared with the noninduced fibroblasts (Figure 1B). BP1 protein expression was found to be tetracycline regulatable when primary fibroblasts were stained for BP1 by immunofluorescence (Figure 1D). Secreted BP1 protein was captured by heparin-affinity chromatography of cell culture supernatants and detected in the $0.9 \mathrm{~mol} / \mathrm{L} \mathrm{NaCl}$ eluate using enzyme-linked immunosorbent assay ${ }^{19}$ and Western blot analysis (Figure 1, E and F). The Western blot showed full-length BP1 protein of $34 \mathrm{kDa}$, as well as fragments of $17 \mathrm{kDa}$ and $14 \mathrm{kDa}$ that were also reported earlier $^{8,45}$ and had led to the original name of BP1, ie, heparin-binding 17-kDa protein ${ }^{8}$ (HBp17). Thus, the BP1 transgene is regulated at the protein level in tissues in vivo and in vitro and is secreted by cells.

\section{Effect of BP1 on MPF Migration}

FGF1 and FGF2 induce migration of cultured primary and embryonic fibroblasts as well as endothelial cells. ${ }^{46-49}$ Moreover, mouse primary dermal fibroblasts and mouse keratinocytes showed enhanced cell motility on addition of exogenous BP1 protein. ${ }^{17}$ Hence, we sought to investigate whether the induction of BP1 would modulate MPF motility in an in vitro wound closure assay. For this, we used time-lapse microscopy to measure the migration rate of MPFs into a denuded area over a 12-hour period. With BP1 ON, the entire denuded area was almost filled by MPFs within 12 hours, whereas with BP1 OFF the MPFs had covered the area only partially (Figure 2, A-C). The addition of FGF2 enhanced migration with BP1 OFF but not with BP1 ON (Figure 2, B and C). This suggests that maximal FGF-driven migration is reached by expression of BP1, although fibroblast proliferation was not affected significantly under the experimental conditions by expression of BP1 (see Supplemental Figure S2 at http://ajp.amjpathol.org). The FGFR kinase inhibitor PD173074 ${ }^{50}$ (Figure 2, A-C) reversed the effect of BP1 expression without affecting the baseline migration rate and also reversed the effect of added FGF2. The findings were corroborated in an independent approach monitoring electric impedance changes in MPFs grown on microelectrodes. With BP1 ON, the migration of MPFs into a denuded area was faster and was inhibited significantly by PD173074. In contrast, with BP1 OFF, PD173074 showed no effect on the slower closure rate (Figure 2, D and $E$ ). These findings suggest that increased motility caused by BP1 requires FGFR signaling. 
A

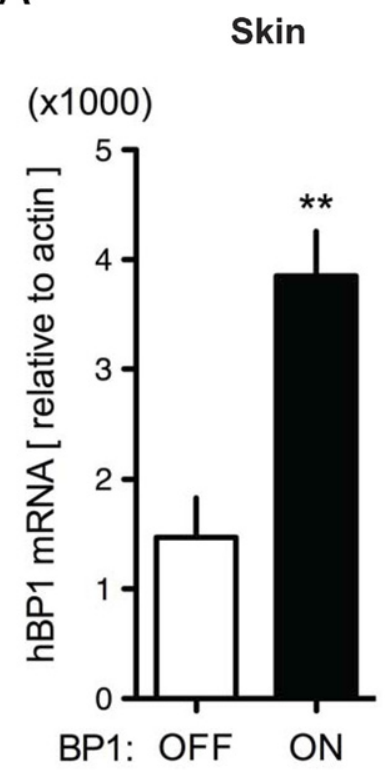

B

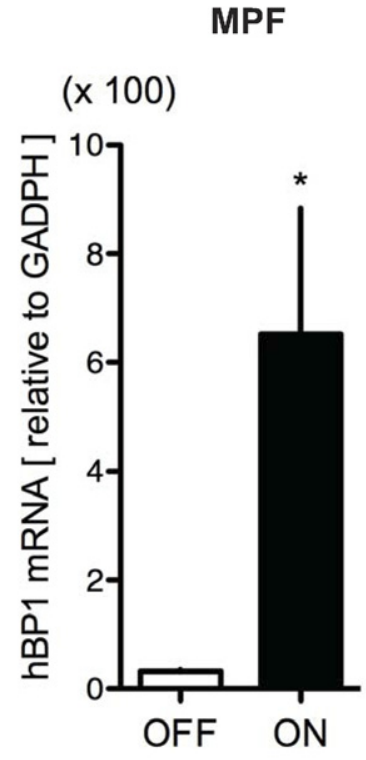

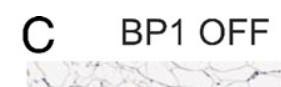

BP1 ON

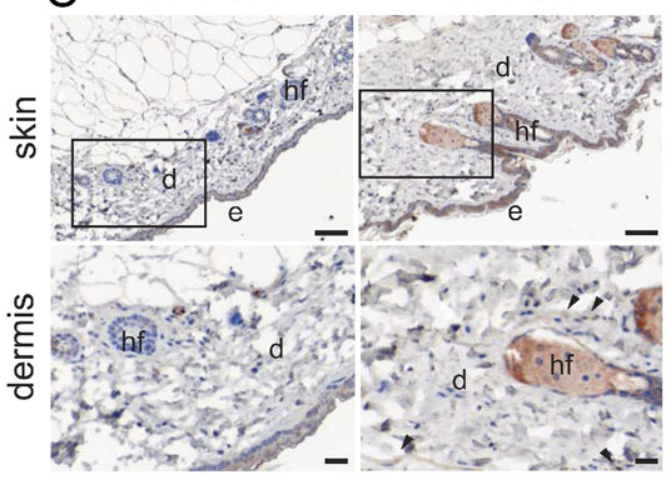

SW13 (BP1 neg.) ME180 (BP1 pos.)

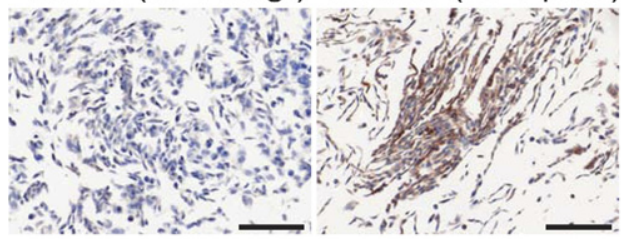

IHC: rabbit anti hBP1

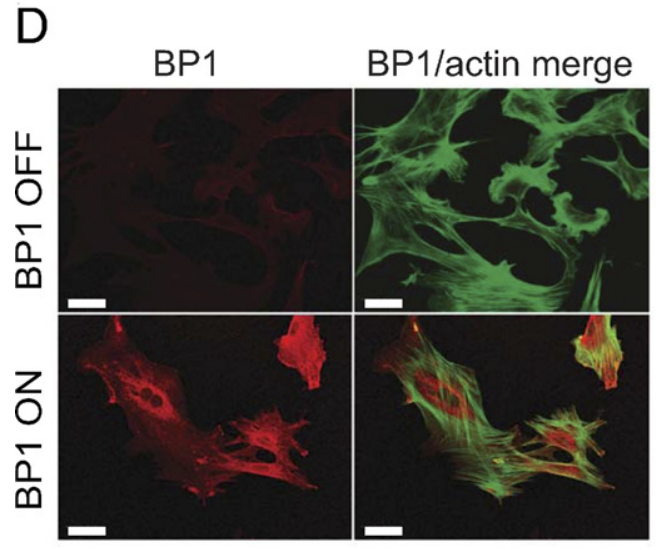

$E$

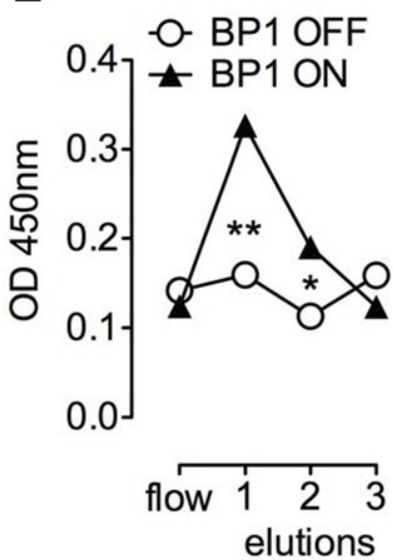

$\mathrm{F}$

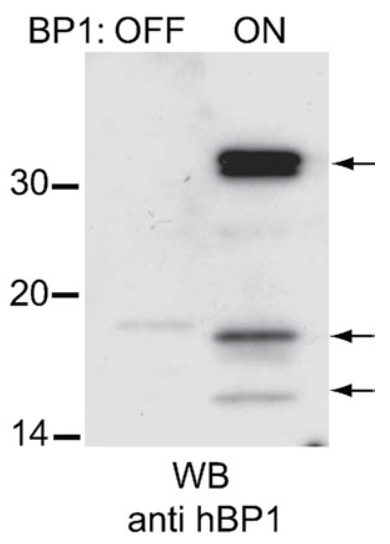

Figure 1. Conditional expression of a human BP1 in skin and transgenic mouse primary fibroblasts (MPF). Transgenic animals carrying a human BP1 cDNA under the control of a tetracycline response element (TRE-BP1) (see Supplemental Figure S1 at bttp://ajp.amjpathol.org) were mated with CMV-tTA (tet-OFF) mice. Transgene expression was suppressed by continuous doxycycline diet (BP1 OFF) or induced by switching the animals to a doxycycline-free diet (BP1 ON) for 2 weeks. A and B: BP1 mRNA expression in mouse skin (A) and in transgenic mouse primary fibroblasts (MPF) (B) was analyzed by qRT-PCR. Expression was normalized to endogenous $\beta$-actin or GADPH mRNA. Data are mean $\pm \mathrm{SEM} ; n=5$. ${ }^{*} P<0.05,{ }^{* *} P<0.01$ BP1 ON versus OFF. C: BP1 protein expression detected by immunohistochemistry of formalin-fixed, paraffin-embedded skin (top) with human cell line controls (bottom). Representative images of BP1 OFF and BP1 ON mouse epithelium and dermis are shown $(n=3)$. Magnified areas are indicated. e, Epidermis; d, dermis; hf, hair follicle. SW13 and ME180 human cell lines served as negative and positive controls for endogenous BP1 expression, respectively. ${ }^{19}$ Immunoreactivity is revealed as an intense brown stain. Size bars: $50 \mu \mathrm{m}$. D: Immunofluorescence staining for BP1 (red) in MPF with the BP1 transgene OFF or ON (+ doxycycline). F-actin staining (green) merged with staining for BP1 (red) is shown in the right panels. Scale bar $=10 \mu \mathrm{m}$. E: BP1 protein in cell supernatants. Conditioned media were passed over heparin-affinity columns, bound proteins were eluted with three $0.9-\mathrm{mol} / 1 \mathrm{NaCl}$ aliquots and assayed for the presence of BP1 by enzyme-linked immunosorbent assay. Data are mean \pm SEM of a representative experiment performed in triplicate. ${ }^{*} P<0.05,{ }^{* *} P<0.01$. F: Western blot analysis of supernatants from MPFs after heparin-affinity chromatography. Arrows indicate BP1 protein fragments of 34, 17, and $14 \mathrm{kDa}$ apparent mass.

\section{BP1 Transgene Expression Promotes Neoangiogenesis in Vivo}

BP1 is an effective modulator of tumor angiogenesis. ${ }^{14,16,51}$ We thus investigated whether BP1 transgene expression would modulate physiological neoangiogenesis induced by a subcutaneous Matrigel plug. BP1 expression indeed resulted in a significant increase in microvessel density (Figure 3, A and B), deeper infiltration of the vessels into the core of the Matrigel plugs (Figure
3, A and C) and a more than threefold increased angiogenesis index (Figure 3D). Systemic treatment of animals with PD173074 inhibited BP1-induced neoangiogenesis in the plugs, without affecting baseline levels (Figure 3B). In independent experiments, treatment with PD173074 also significantly inhibited FGF2-induced neoangiogenesis in Matrigel plug assays (see Supplemental Figure S3 at $h$ ttp://ajp.amjpathol.org). From this, we conclude that BP1 expression in vivo modulates neoangiogenesis via FGFR activation. It is noteworthy that nontransgenic litter- 
B

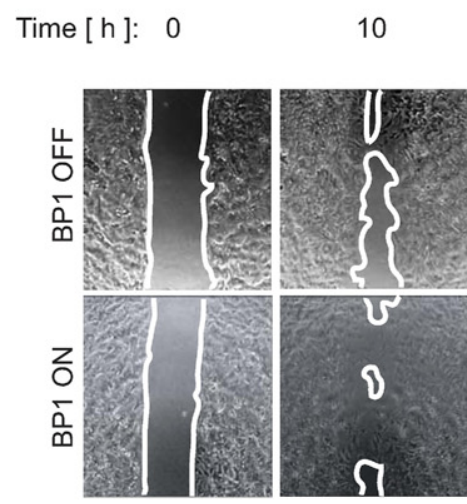

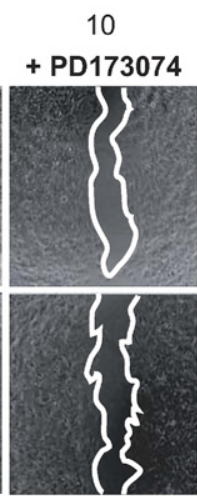

BP1 OFF

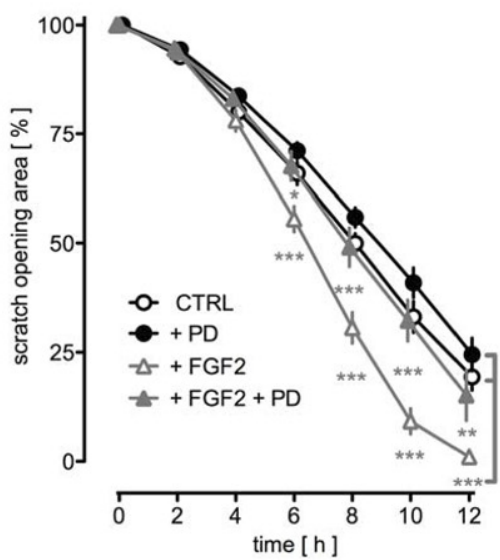

C

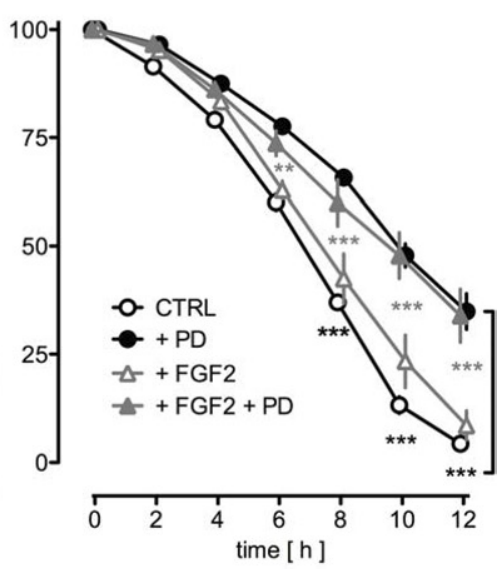

D

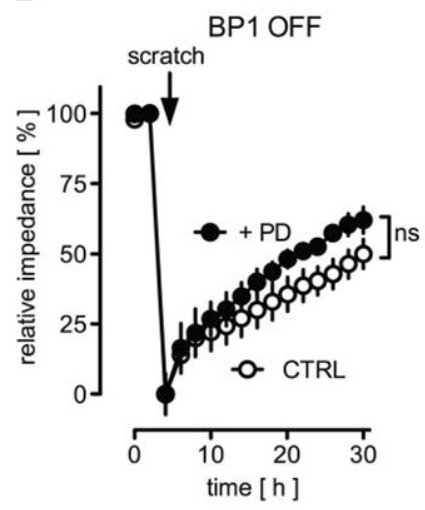

E

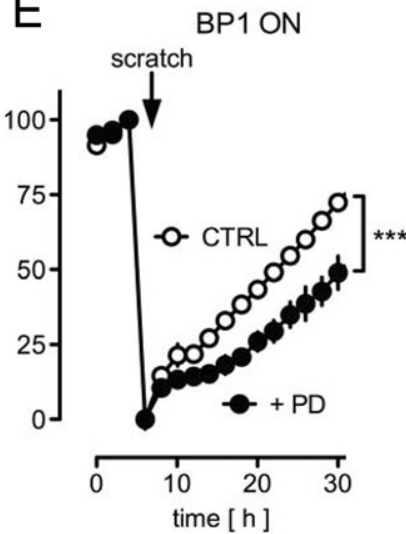

Figure 2. BP1 expression accelerates migration of transgenic mouse primary fibroblasts (MPFs). A: Migration into an open tissue culture area was followed by time-lapse photomicroscopy. Representative images at 0 hours and after 10 hours of migration in the absence or in the presence of the FGFR kinase inhibitor PD173074 are shown. White lines indicate migration front of the cells. $\mathbf{B}$ and $\mathbf{C}$ : Quantitation of the migration expressed as a percentage of the open area over 12 hours. BP1 OFF $(\mathbf{B})$ or BP1 ON $(\mathbf{C})$ MPFs with different treatments. Mean \pm SEM, $n=3 ;{ }^{*} P<0.05,{ }^{* *} P<0.01 ;{ }^{\text {*al }} P<0.0001$ BP1 OFF + FGF2 versus BP1 OFF + FGF2 + PD173074; * * $P<0.0001 \mathrm{BP} 1 \mathrm{OFF}+\mathrm{FGF} 2$ versus BP1 OFF CTRL and BP1 OFF + PD173074 (bracket in B); ${ }^{\text {*ak }} P<0.01$; *woper $P<$ $0.0001 \mathrm{BP} 1 \mathrm{ON}+\mathrm{FGF} 2$ versus BP1 ON + FGF2 + PD173074; ${ }^{\text {wal }} P<0.0001$ BP1 ON CTRL versus BP1 ON + PD173074 (bracket in C). D and E: Migration of MPFs into a denuded area was monitored by electric impedance of the cell layer. The impedance before scratching was set at 100\% while the trough after wounding was set as $0 \%$. The data are representative of at least three independent experiments done in duplicate. ns, $P>0.05$; ${ }^{\text {*ate }} P<0.0001$ BP1 ON CTRL versus BP1 ON + PD173074. mates showed no effect of a tetracycline diet switch that is used to induce BP1 transgene expression (see Supplemental Figure S4 at http://ajp.amjpathol.org).

\section{Wound Healing After Expression of BP1}

\section{Macroscopic Analysis}

Topical application of recombinant FGF2 to skin wounds accelerates their healing. ${ }^{40,52,53}$ Complementary to this, FGF2-null mice show delayed wound healing. ${ }^{27}$ Based on these observations, we investigated the impact of BP1 transgene expression on the healing of full-thickness skin wounds. A macroscopic analysis of the closure of wounds is shown in Figure 4A. To compare wound healing among the different groups of animals, the wound areas were photographed daily and the open wound areas quantitated by image analysis (Figure 4B, inset). A $>50 \%$ reduction of the initial wound area was used as a macroscopic indicator of wound closure. Using these criteria, we found that expression of BP1 accelerates closure of the wounds significantly relative to the respective controls (Figure $4 \mathrm{~B} ; P<0.01)$. Systemic treatment of animals with the FGFR kinase inhibitor PD $173074^{50}$ reversed the effect of BP1 expression on wound healing (Figure 4B; $P<$ $0.0001)$. Treatment with PD173074 also appeared to delay wound healing in the control group slightly, al- though the effect was not statistically significant (Figure 4B; $P>0.05$ ). Analysis of the absolute wound sizes also showed significantly faster closure with BP1 ON that was delayed by PD173074 treatment (Figure 4B, inset).

\section{Microscopic Analysis}

At day 3 postinjury, excisional full-thickness wounds of BP1 ON mice were similar in size and appearance relative to those of BP1 OFF littermates and were filled by a scab, organized fibrin, and polymorphonuclear neutrophils (PMNs) (see Supplemental Figure S5 at http:// ajp.amjpathol.org). However, wounds showed faster closure with the induction of BP1 expression that was apparent as soon as 4 days postinjury and that coincided with an increase in myofibroblasts as indicated by $\alpha$-smooth muscle actin staining (Figure 5B). Histological sections at different times after excisional wounding showed advanced fibrin breakdown (Figure 5A, asterisks) as well as increased numbers of infiltrating fibroblasts, macrophages and blood vessels (Figure 5A, arrowheads) when BP1 was expressed. Also, spindle fibroblasts extended across the full width of the wounds with parallel streaks of cells oriented toward the center of the wound. At day 6 , granulation tissues exhibited an almost complete absorption of fibrin, cells infiltrating in a mature arrangement and a high number of branched microves- 
A

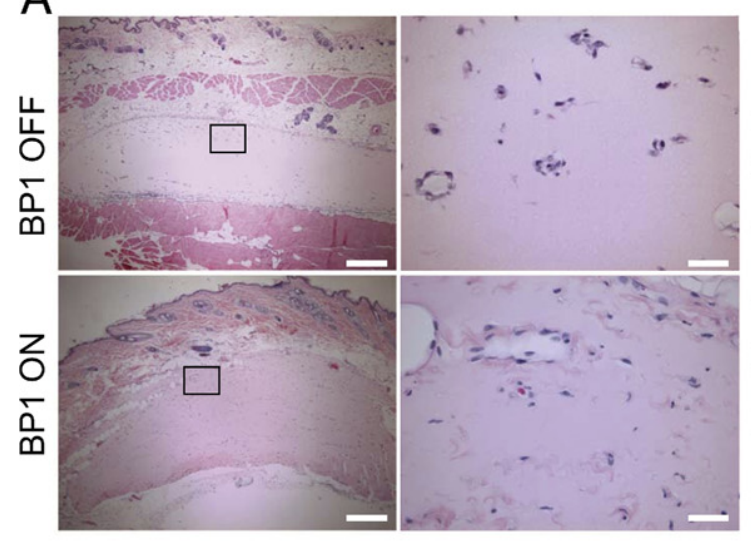

B

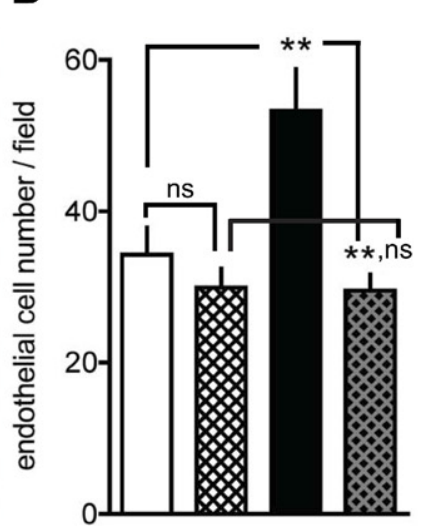

PD:

$\frac{-+}{\text { BP1 OFF }} \frac{-}{\text { BP1 ON }}$
C

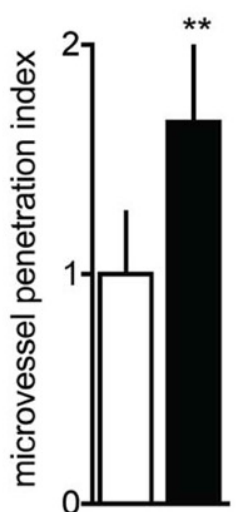

BP1: $0^{\ll}$ or
D

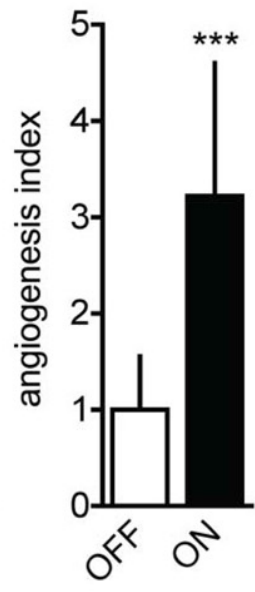

Figure 3. BP1 expression enhances neoangiogenesis in subcutaneous Matrigel plugs. A: Representative cross-sections of H\&E-stained Matrigel plugs harvested 4 days after implantation into mice with the BP1 transgene OFF or ON. The rectangles represent magnified areas shown in the right column. Scale bars: $250 \mu \mathrm{m}$ (left panels), $25 \mu \mathrm{m}$ (right panels). B-D: Quantitation of neoangiogenesis. B: Number of endothelial cell nuclei in the matrigel implants from 10 high-power fields under BP1 OFF and BP1 ON condition + treatment of animals with the FGFR kinase inhibitor PD173074 (PD, $1 \mathrm{mg} / \mathrm{kg} /$ day intraperitoneally starting 2 days before the Matrigel implants). C: Penetration of new vessels into the implants (area of vessels/overall Matrigel area). D: Angiogenesis index (endothelial cell number $\times$ penetration). Data are mean \pm SEM; $n=4$ to 10 animals per experimental condition. ${ }^{\mathrm{ns}} P>0.05,{ }^{* * *} P<0.01$ and ${ }^{* * * * *} P<0.0001$.

sels (Figure 5A, arrows). In contrast, without induction of BP1 expression, dissolution of the fibrin clots and nonpolarized fibroplasia was only initiated at day 5 and neoangiogenesis was relatively immature at that time point with few, unbranched microvessels. Wounds from BP1 expressing mice were nearly completely epithelialized by day 6 , whereas controls lacked epithelial closure at that time (Figure 5A, black arrows, and Figure 6A), which also matched the distinct time to wound healing observed by the macroscopic analysis (Figure 4). Microscopic analysis of wounds at day 6 did not reveal an obvious difference in wound closure after PD173074 treatment. However, the PD173074-treated BP1 ON group showed reduced granulation tissue remodeling, apparent when

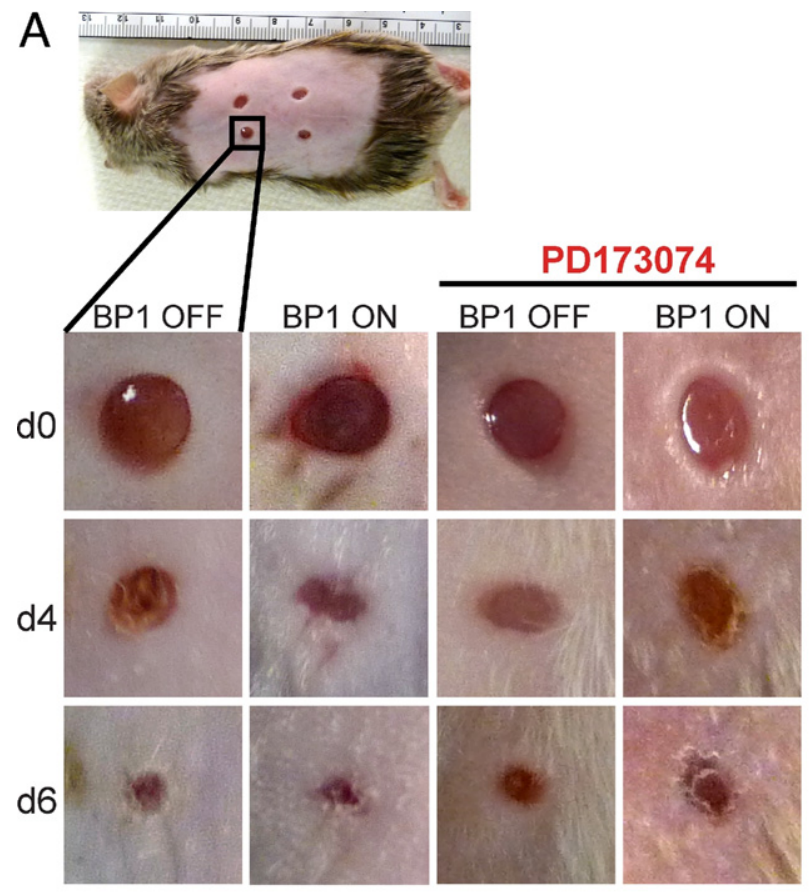

B

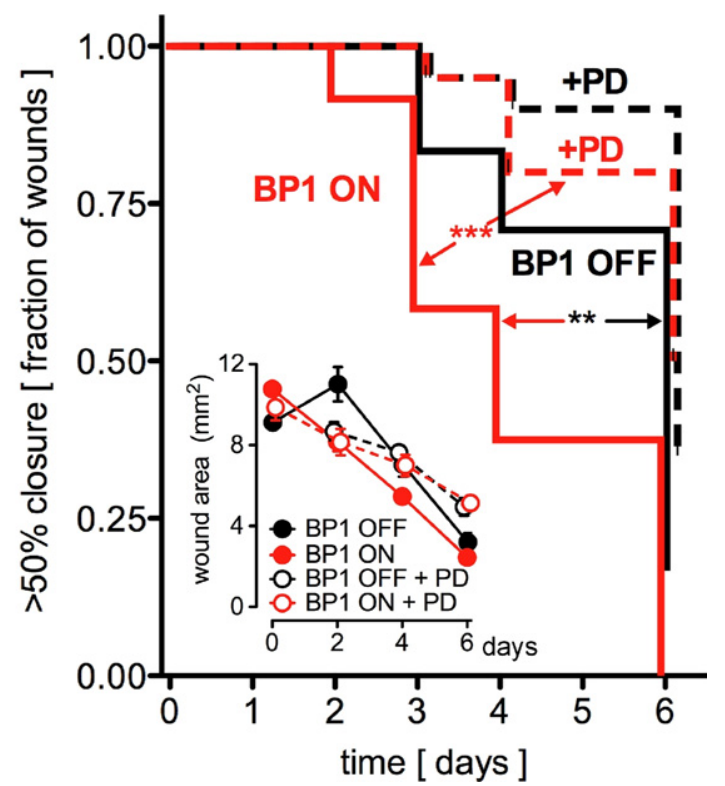

Figure 4. BP1 expression accelerates wound healing in vivo. A: Representative macroscopic images of full-thickness dorsal skin wounds in BP1 OFF and BP1 ON mice at day 0,4 , and 6 post injury without or with daily intraperitoneal injection of the FGFR kinase inhibitor PD173074 (1 mg/kg/day). B: Kaplan-Meier analysis of the rate of wound healing. The open wound areas were quantitated by daily image analysis (inset). The time to wound closure by $>50 \%$ is shown ( $n=5-6$ mice/group, 4 wounds/mouse). ${ }^{* *} P<0.01$ BP1 ON versus OFF; ${ }^{* * *} P<0.0001$ BP1 ON versus BP1 ON + PD173074. Inset: Quantitation of the wound area of full-thickness dorsal skin wounds at day $0,2,4$ and 6 postinjury. $P<0.01$ BP1 ON at day 2 postinjury versus day 0 . Wound closure in BP1 ON animals treated with PD173074 was delayed to day $4(P<0.01)$. By day 6 postinjury, all wounds were significantly different those on from day 0 . **** $P<0.0001$. 
A
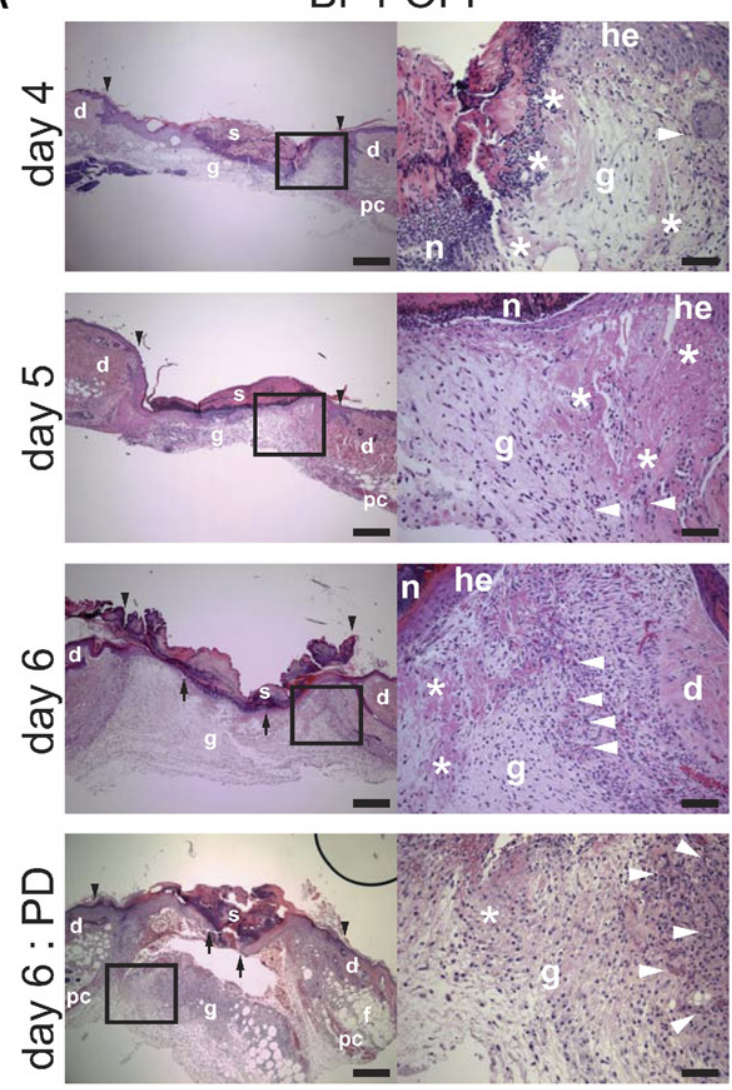

B PCNA (day 4)

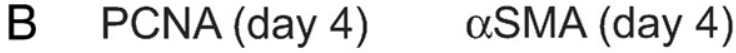

BP1 ON
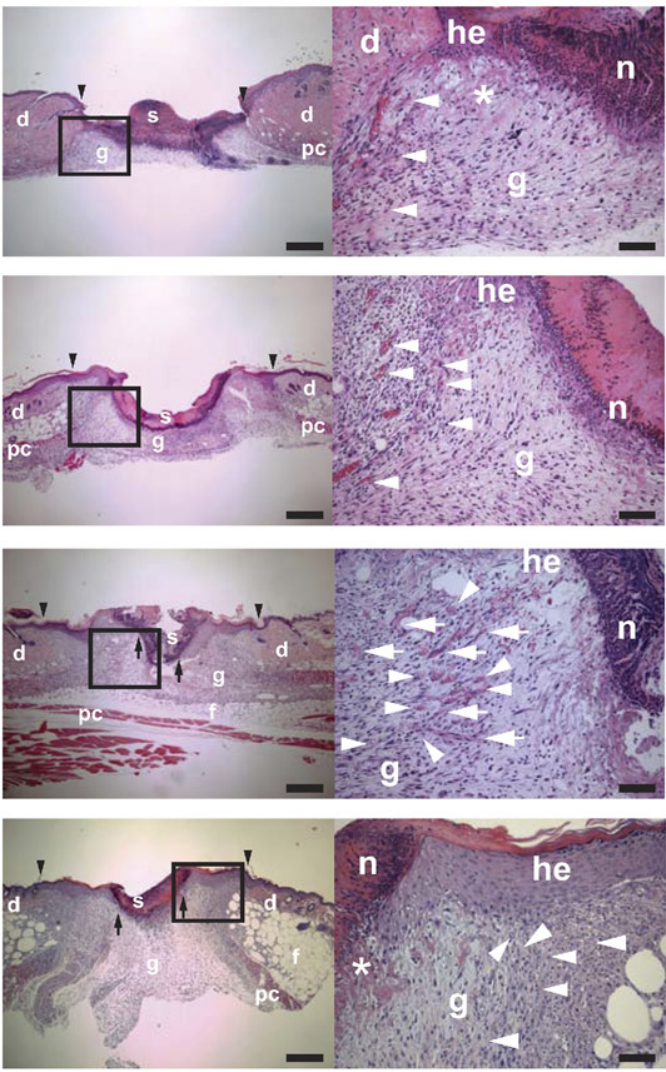

F4/80 (day 5)

\section{CD31 (day 5)}

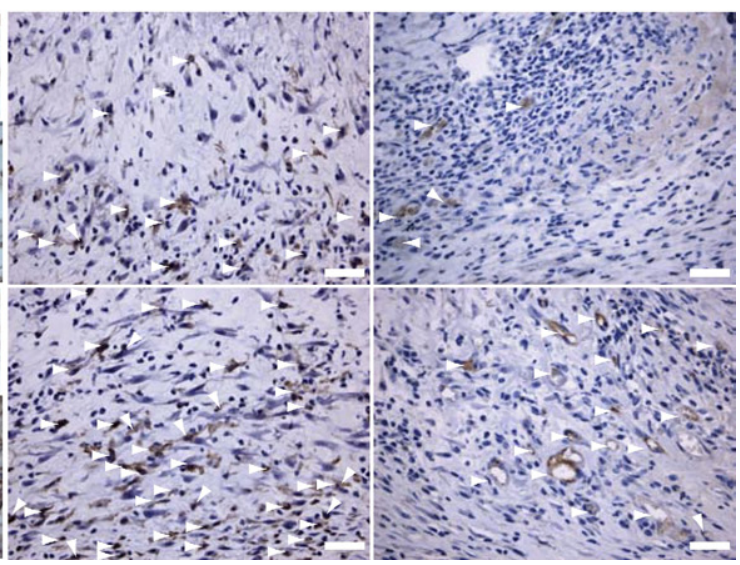

Figure 5. Effect of BP1 expression on wound healing. A: Representative H\&E-stained sections of excisional skin wounds from transgenic mice with BP1 OFF or ON at different times after wounding (day 4, 5, and 6) and at day 6 after wounding after PD173074 treatment ( $1 \mathrm{mg} / \mathrm{kg} /$ day intraperitoneally). Magnified areas shown on the right are indicated. Scale bars: $250 \mu \mathrm{m}$ (low magnification); $50 \mu \mathrm{m}$ (high magnification). Abbreviations: $\mathrm{s}$, scab; g, granulation tissue; $\mathrm{d}=\mathrm{dermis}$ he, hyperproliferative epithelium; n, polymorphonuclear neutrophils; pc, panniculus carnosus; f, subcutaneous fat layer. Black arrowheads indicate wound edges; black arrows, tips of epithelial tongues, asterisk, fibrin clot; white arrowheads, capillaries; and white arrows, branched microvessels. Details are provided in Results. B: Staining of granulation tissues for cell proliferation (PCNA), myofibroblasts ( $\alpha$ SMA), macrophages (F4/80), and microvessels (CD31). For Proliferating cell nuclear antigen (PCNA) staining arrowheads indicate cells with PCNA-positive nuclei. For anti- $\alpha$ SMA staining the arrowheads in the inset indicate cytoplasmic staining of $\alpha \mathrm{SMA}$-positive myofibroblasts. For anti- $\mathrm{F} 4 / 80^{41}$ staining, arrowheads indicate cytoplasmic staining of $\mathrm{F} 4 / 80$-positive macrophages. For anti-CD31 staining, arrowheads indicate CD31-positive microvessels. Scale bars $=25 \mu \mathrm{m}$. Quantitation of the stainings is shown in Figure 6, B-D

comparing the number of microvessels in the different groups (Figures 5A and 6G).

The degree of infiltration of granulation tissue by fibroblasts and macrophages is a good indicator of the progress of wound repair. ${ }^{23,33}$ We observed significantly more infiltrating cells in granulation tissues with
BP1 expression from day 4 of wound healing onwards (Figure 6E; see also Supplemental Figure S6 at $h t t p: / /$ ajp.amjpathol.org). We found greater than threefold more macrophages in the wound margins when BP1 gene expression was induced (Figures 5B and 6C). In addition, infiltrating cells in the granulation tissue 
A

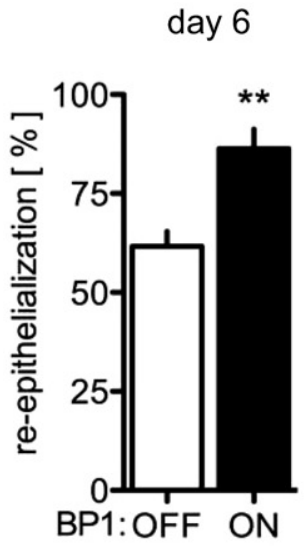

E Cellular infiltration score

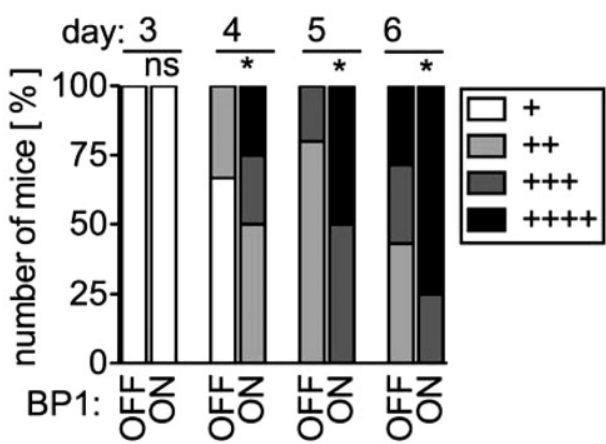

B

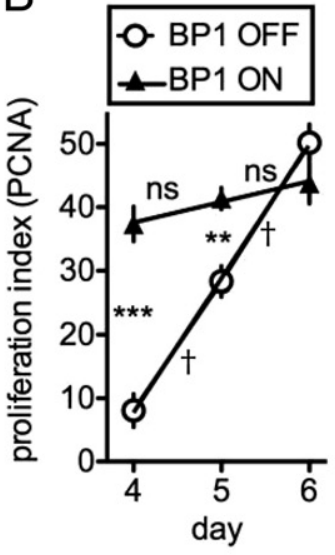

C day 5

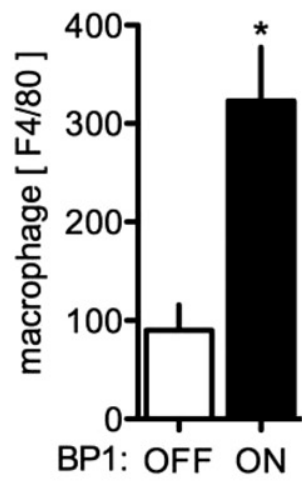

F Angiogenesis score

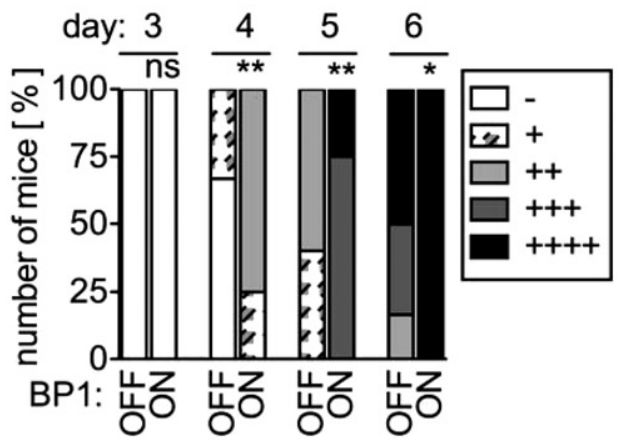

D day 5

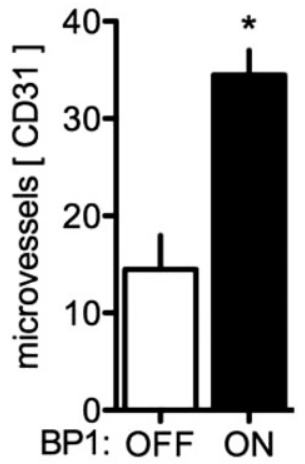

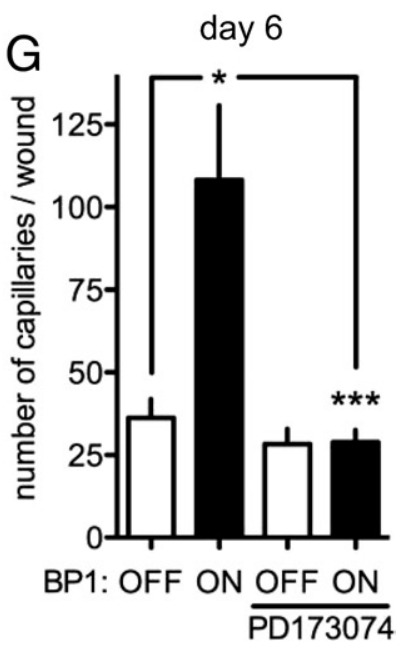

Figure 6. Effect of BP1 expression on wound re-epithelialization, cellular infiltration, macrophage invasion, cell proliferation, and neoangiogenesis. A Quantitation of wound re-epithelialization 6 days postinjury in BP1 OFF versus ON animals (mean \pm SEM; $n=9$ ). Re-epithelialization was quantified as described in Materials and Methods. ${ }^{* *} P<0.01$ BP1 ON versus OFF. B: Proliferation index of cells in the granulation tissue (PCNA-positive fraction) measured at days 4,5 , and 6 postinjury. Differences between time points: ns, $P>0.05 ;{ }^{\dagger} P<0.0001$ or between BP1 OFF and ON: ${ }^{* *} P<0.01$; *** $P<0.0001$. C: Number of F4/80-positive macrophages invading the granulation tissue 5 days postinjury $(* P<0.05)$. D: Number of CD31-positive microvessels in the granulation tissue 5 days postinjury $(* P<0.05)$. E: Cellular infiltration of granulation tissue was scored semiquantitatively. H\&E-stained slides of wounds harvested at different times after wounding under BP1 OFF or ON conditions were used. ns, $P>0.05 ;{ }^{*} P<0.05$; calculated by $\chi^{2}$ test (scoring standards are available in Supplemental Figure S3, available at http://ajp.amjpathol.org). F: Neoangiogenesis was scored in the H\&E-stained wounds at different times after wounding under BP1 OFF or ON conditions. Symbols: - denotes 0 to $4,+$ denotes 5 to $14,++$ denotes 15 to $24,+++$ denotes $25-35$, and ++++ dennotes 36-45 capillaries throughout the granulation tissue). ns, $P>0.05$; ${ }^{*} P<0.05 ; * * P<0.01$, calculated by a $\chi^{2}$ test. G: Quantitation of neocapillaries in the granulation tissues from H\&E-stained wound sections at day 6 postwounding from BP1 OFF and BP1 ON animals \pm PD 173074 treatment. ${ }^{*} P<0.05$, BP1 ON versus BP1 OFF; ${ }^{* * *} P<0.0001, \mathrm{BP} 1 \mathrm{ON}+\mathrm{PD} 173074$ versus BP1 ON. Representative H\&E stainings and immunohistochemical images are shown in Figure 5.

showed a high proliferation index ( $>30 \%$ of cells PCNA positive) at earlier times in the BP1 ON group, coinciding with a faster wound healing process (Figures $5 \mathrm{~B}$ and $6 \mathrm{~B}$ ). However, keratinocytes in the hyperproliferative epithelium of BP1 OFF and BP1 ON mice did not show any difference in proliferation as assessed by PCNA staining (see Supplemental Figure S7 at http://ajp.amjpathol.org), suggesting that, at day 6 postinjury, BP1 may enhance keratinocyte migration. Thus, BP1 is likely to play a major role in the remodeling of the granulation tissue.

The ingrowth of new vessels into a wounded area is required to initiate and to complete healing. We observed a significantly more efficient ingrowth of new vessels into the wounds of animals with BP1 expression induced (Figure 6, D and F) that was also visible by staining for CD31-positive microvessels (Figure 5B, right panel). The number of microvessels in the wounds of BP1 ON versus OFF animals were increased by greater than threefold at day 6. Treatment with PD173074 reversed this BP1 driven wound angiogenesis at day 6 without a significant effect on baseline wound angiogenesis (Figure 6G). Thus, expression of BP1 can drive accelerated angiogenesis in healing skin wounds.

\section{Angiogenesis in the Mouse Ischemic Hindlimb After BP1 Induction}

Finally, the effects of BP1 expression were assessed in a separate model of internal tissue damage repair. For this, we induced ischemic injury in hindlimb muscles by ligation of the femoral artery and observed the impact of BP1 

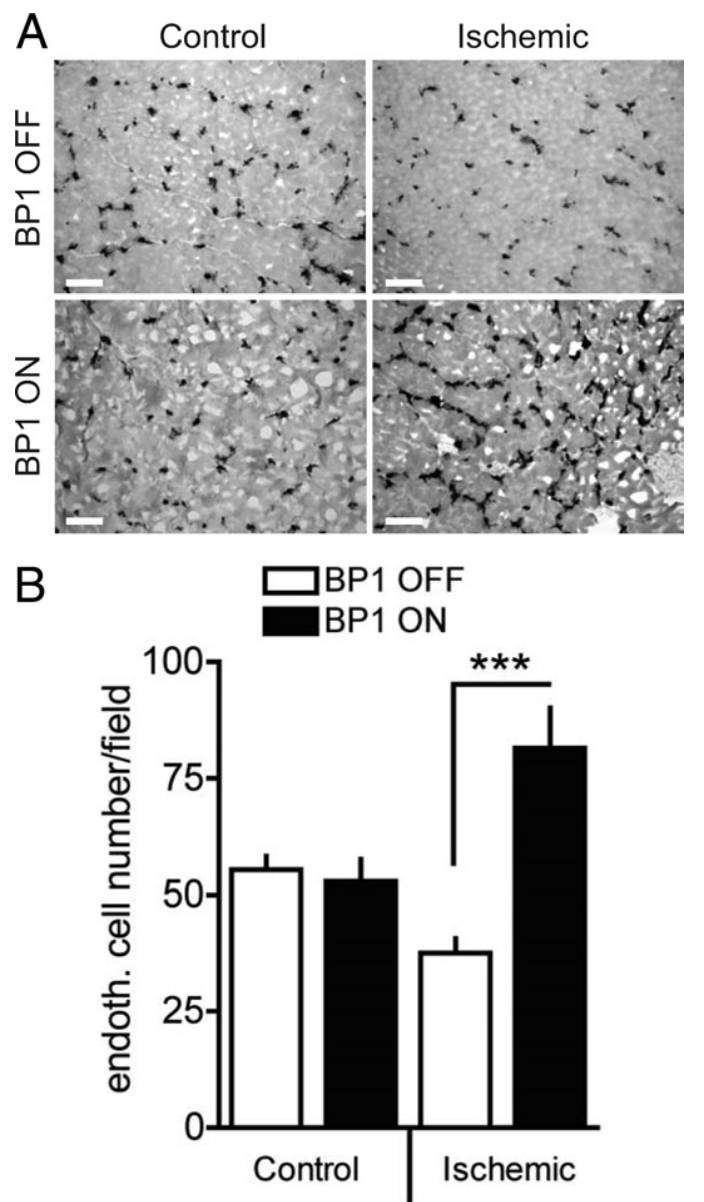

Figure 7. Enhanced neoangiogenesis in ischemic hindlimbs of BP1-expressing mice. A: Representative images of CD31 immunohistochemistry in ischemic and nonischemic adductor muscles of BP1 OFF and BP1 ON mice 30 days after the ischemic injury. Scale bars $=25 \mu \mathrm{m}$. B: Density of CD31positive capillaries in ischemic and nonischemic adductor muscles. Data are mean \pm SEM, $n=3$ to $4 .{ }^{* * * * *} P<0.0001$

transgene expression on the formation of collateral vessels, as described by investigators at the Schaper laboratory. ${ }^{54}$ Nonischemic muscle tissues showed a similar vessel density (by CD31 staining) irrespective of BP1 expression (Figure 7, A and B). In muscle tissues harvested 1 month after ischemic injury, a significant increase of newly formed vessels above control (Figure 7, $A$ and B) was observed only when BP1 was expressed. Hence, BP1 expression can stimulate neoangiogenesis and collateral formation after ischemic injury of muscle tissues.

\section{Discussion}

Previous attempts to generate BP1 transgenic mice under a constitutively active promoter, ie, CMV, MMTV or $\mathrm{K} 14$, did not result in viable offspring because of hemorrhage in the gestational sac ${ }^{37}$ (unpublished results). Embryonic death as a result of vascular leakage and hemorrhage were also observed when the BP1 or the homologous BP3 gene were expressed in chick embryos by microinjection. 9,37 We found that vascular leakage is caused by the release of locally stored FGFs by BPs, can be mimicked by expression of a secreted form of FGF1, ${ }^{37}$ and leads to FGFR activation that is inhibited by PD173074. ${ }^{9}$

Here we report that conditional expression of a BP1 transgene in adult animals can circumvent embryonic lethality, and thus allowed us to study the impact of BP1 expression in the mature organism. The BP1 transgene is inducible at the protein level as shown by staining of formalin-fixed, paraffin-embedded mouse tissues and IP/Western of tissue lysates. The analysis of the protein in cultured primary fibroblasts derived from the transgenic animals reported here shows that the protein is processed and released to the extracellular milieu as observed earlier for the endogenous BP1 protein.

When challenged with a subcutaneous Matrigel implant, a significant increase of neoangiogenesis was observed in BP1-expressing mice, as compared with tetracycline-treated controls. We saw an increased number of microvessels as well as a higher degree of infiltration into the Matrigel plugs. In contrast, plugs from control mice were invaded by fewer microvessels, the localization of which was limited to the periphery of the Matrigel implant (Figure 3). This increase in BP1-induced neoangiogenesis was blocked by a systemically administered FGFR kinase inhibitor, PD173074, that is known to act on FGFR $1^{50}$ as well as FGFR2 and FGFR3. ${ }^{1}$ This finding supports the proposed mechanism of action of BP1 via activation of the FGF receptor pathway in vivo. ${ }^{11,14,16}$

Several members of the FGF family are expressed in normal skin and FGF1, -2, and -7 were found upregulated after skin injury. ${ }^{26}$ Our studies show a significant role of BP1 as a modulator of FGF activity during this process. The macroscopic analysis reveals accelerated wound closure after BP1 expression and the reversal of this effect by treatment of the animals with the PD173074 FGFR kinase inhibitor supports the notion that FGFR signaling is rate limiting for the effect of BP1 (Figure 4). Inflammatory, proliferative and angiogenic phases of wound healing examined in BP1-expressing mice showed faster progression of wound healing relative to the controls. Also, expression of the BP1 transgene resulted in a higher degree of wound re-epithelialization. This matches with previous reports that showed the stimulatory effect of FGF2 on keratinocyte proliferation, ${ }^{55}$ although FGF7, -10, and -22 are better mitogens for keratinocytes and also bind to BP1. ${ }^{10}$

Wounds from BP1-overexpressing mice displayed a significant increase of the number of macrophages recruited (Figures 5B and 6C). During the inflammatory phase of wound healing, neutrophils and macrophages are the main infiltrates in the wound site. Macrophages are responsible for secreting a plethora of biologically active growth factors, such as FGFs, PDGF, and vascular endothelial growth factor and pro-inflammatory cytokines, such as transforming growth factor $-\alpha$, transforming growth factor- $\beta$, interleukin 6 , and $p 43 .^{56,57}$ Also, several reports have demonstrated the importance of macrophages in the healing process. For instance, prevention of macrophage infiltration is responsible for a 
severe wound healing impairment ${ }^{58}$ and interleukin-6deficient or intracellular adhesion molecule 1-deficient mice show decreased macrophage infiltration as well as compromised skin wound healing. ${ }^{59-62}$

The increase in BP1-dependent FGF bioavailability in the wound sites can account for the higher number of fibroblasts migrating into the stromal tissue of wounds of BP1-expressing mice (Figures 5A and 6E). Enhanced migration of cultured primary fibroblasts resulting from BP1 expression (Figure 2) is an in vitro correlate of this in vivo effect. As a consequence of the enhanced FGFmediated chemoattraction of fibroblasts, macrophages, and endothelial cells into the granulation tissue, we detected a peak in the cell proliferation rate as early as 4 days postinjury (Figure 6B). Similar levels of cell proliferation were reached in control animals, only with a 2-day delay. However, keratinocyte proliferation was not affected by BP1 expression (see Supplemental Figure S7 at $h t t p: / / a j p . a m j p a t h o l . o r g)$. Moreover, we found a remarkable increase in the number of newly generated microvessels in the skin wounds as well as increased collateral formation in ischemic skeletal muscles in BP1expressing mice (Figure 7).

Very similar to this enhanced wound repair, endogenous BP1 expression was recently shown to modulate the effect of FGFs in the maintenance and reinnervation of the neuromuscular junction, as reviewed elsewhere. ${ }^{22}$ In these studies, down-regulation of BP1 was linked to a lack of reinnervation during the progression of amyotrophic lateral sclerosis (ALS) ${ }^{21}$ On the other hand, BP1 expression was found upregulated in blood vessels of mice that succumb to premature atherogenesis, ${ }^{63}$ a disease that is linked to inflammation and pathological repair of vascular endothelia. Furthermore, BP1 was found to be upregulated after spinal cord injury and in HIV-induced kidney damage, ${ }^{64,65}$ in different malignancies such as colon, breast, prostate, ${ }^{19,44,66}$ and skin cancers, ${ }^{17}$ and has been proposed as an angiogenic switch that is turned on during malignant progression. ${ }^{16}$ These findings suggest that BP1 can play a role in the maintenance and repair, as well as the pathology, of a variety of tissues.

\section{Conclusions}

To the best of our knowledge, this study provides the first evidence that conditional expression of BP1 can enhance wound healing by driving neo-angiogenesis, fibroblast migration, macrophage recruitment, and epithelial closure. It is conceivable that exogenous administration of BP1 protein may enhance the activity of locally stored FGFs or of exogenously administered FGFs that are used in clinical trials for different indications, including wound healing and cardiovascular disease (see http://ClinicalTrials.gov). The phenotypic similarity of wound healing and repair with cancer initiation and progression has been well established, and overlapping drivers have been identified. ${ }^{67-69}$ Similarities between wound healing and malignant transformation were described 150 years ago by Rudolf Virchow. ${ }^{70} \mathrm{He}$ proposed that tissue injury and scarring are part of the etiology of malignancies, and it does appear that FGFBPs carry the hallmarks of common drivers that can link these distinct pathological events.

\section{Acknowledgments}

We thank Moira Hilscher and Drs. Angera Kuo and Ralf T. Henke for experimental assistance.

\section{References}

1. Beenken A, Mohammadi M: The FGF family: biology, pathophysiology and therapy. Nat Rev Drug Discov 2009, 8:235-253

2. Dailey L, Ambrosetti D, Mansukhani A, Basilico C: Mechanisms underlying differential responses to FGF signaling. Cytokine Growth Factor Rev 2005, 16:233-247

3. Mohammadi M, Olsen SK, Ibrahimi OA: Structural basis for fibroblast growth factor receptor activation. Cytokine Growth Factor Rev 2005, 16:107-137

4. Powers CJ, McLeskey SW, Wellstein A: Fibroblast growth factors, their receptors and signaling. Endocr Relat Cancer 2000, 7:165-197

5. Saksela O, Moscatelli D, Sommer A, Rifkin DB: Endothelial cellderived heparan sulfate binds basic fibroblast growth factor and protects it from proteolytic degradation. J Cell Biol 1988, 107:743-751

6. Moscatelli D: Basic fibroblast growth factor (bFGF) dissociates rapidly from heparan sulfates but slowly from receptors. Implications for mechanisms of bFGF release from pericellular matrix, J Biol Chem 1992, 267:25803-25809

7. Turner N, Grose R: Fibroblast growth factor signalling: from development to cancer. Nat Rev Cancer 2010, 10:116-129

8. Wu DQ, Kan MK, Sato GH, Okamoto T, Sato JD: Characterization and molecular cloning of a putative binding protein for heparin-binding growth factors. J Biol Chem 1991, 266:16778-16785

9. Zhang W, Chen Y, Swift MR, Tassi E, Stylianou DC, Gibby KA, Riegel AT, Wellstein A: Effect of FGF-binding protein 3 on vascular permeability. J Biol Chem 2008, 283:28329-28337

10. Beer HD, Bittner M, Niklaus G, Munding C, Max N, Goppelt A, Werner $\mathrm{S}$ : The fibroblast growth factor binding protein is a novel interaction partner of FGF-7. FGF-10 and FGF-22 and regulates FGF activity: implications for epithelial repair, Oncogene 2005, 24:5269-5277

11. Czubayko F, Smith RV, Chung HC, Wellstein A: Tumor growth and angiogenesis induced by a secreted binding protein for fibroblast growth factors. J Biol Chem 1994, 269:28243-28248

12. Mongiat M, Otto J, Oldershaw R, Ferrer F, Sato JD, Iozzo RV: Fibroblast growth factor-binding protein is a novel partner for perlecan protein core. J Biol Chem 2001, 276:10263-10271

13. Xie B, Tassi E, Swift MR, McDonnell K, Bowden ET, Wang S, Ueda Y, Tomita $Y$, Riegel AT, Wellstein A: Identification of the fibroblast growth factor (FGF)-interacting domain in a secreted FGF-binding protein by phage display. J Biol Chem 2006, 281:1137-1144

14. Tassi E, Al-Attar A, Aigner A, Swift MR, McDonnell K, Karavanov A, Wellstein A: Enhancement of fibroblast growth factor (FGF) activity by an FGF-binding protein. J Biol Chem 2001, 276:40247-40253

15. Gibby KA, McDonnell K, Schmidt MO, Wellstein A: A distinct role for secreted fibroblast growth factor-binding proteins in development, Proc Natl Acad Sci USA: 2009, 106:8585-8590

16. Czubayko F, Liaudet-Coopman ED, Aigner A, Tuveson AT, Berchem GJ, Wellstein A: A secreted FGF-binding protein can serve as the angiogenic switch in human cancer. Nat Med 1997, 3:1137-1140

17. Kurtz A, Aigner A, Cabal-Manzano RH, Butler RE, Hood DR, Sessions RB, Czubayko F, Wellstein A: Differential regulation of a fibroblast growth factor-binding protein during skin carcinogenesis and wound healing. Neoplasia 2004, 6:595-602

18. Kurtz A, Wang HL, Darwiche N, Harris V, Wellstein A: Expression of a binding protein for FGF is associated with epithelial development and skin carcinogenesis. Oncogene 1997, 14:2671-2681

19. Tassi E, Henke RT, Bowden ET, Swift MR, Kodack DP, Kuo AH, Maitra A, Wellstein A: Expression of a fibroblast growth factor-binding pro- 
tein during the development of adenocarcinoma of the pancreas and colon. Cancer Res 2006, 66:1191-1198

20. Tassi E, Wellstein A: The angiogenic switch molecule, secreted FGFbinding protein, an indicator of early stages of pancreatic and colorectal adenocarcinoma. Semin Oncol 2006, 33:S50-56

21. Williams AH, Valdez G, Moresi V, Qi X, McAnally J, Elliott JL, BasselDuby R, Sanes JR, Olson EN: MicroRNA-206 delays ALS progression and promotes regeneration of neuromuscular synapses in mice. Science 2009, 326:1549-1554

22. Brown $\mathrm{RH}$ : Medicine. A reinnervating microRNA, Science 2009, 326 : 1494-1495

23. Gurtner GC, Werner S, Barrandon Y, Longaker MT: Wound repair and regeneration. Nature 2008, 453:314-321

24. Barrientos S, Stojadinovic O, Golinko MS, Brem H, Tomic-Canic M: Growth factors and cytokines in wound healing. Wound Repair Regen 2008, 16:585-601

25. Braun S, auf dem Keller U, Steiling H, Werner S: Fibroblast growth factors in epithelial repair and cytoprotection. Philos Trans R Soc Lond B Biol Sci 2004, 359:753-757

26. Werner S, Peters KG, Longaker MT, Fuller-Pace F, Banda MJ, Williams LT: Large induction of keratinocyte growth factor expression in the dermis during wound healing, Proc Natl Acad Sci USA: 1992 89:6896-6900

27. Ortega S, Ittmann M, Tsang SH, Ehrlich M, Basilico C: Neuronal defects and delayed wound healing in mice lacking fibroblast growth factor 2, Proc Natl Acad Sci USA: 1998, 95:5672-5677

28. Guo L, Degenstein L, Fuchs E: Keratinocyte growth factor is required for hair development but not for wound healing. Genes Dev 1996, 10:165-175

29. Miller DL, Ortega S, Bashayan O, Basch R, Basilico C: Compensation by fibroblast growth factor 1 (FGF1) does not account for the mild phenotypic defects observed in FGF2 null mice. Mol Cell Biol 2000, 20:2260-2268

30. Broadley KN, Aquino AM, Woodward SC, Buckley-Sturrock A, Sato Y, Rifkin DB, Davidson JM: Monospecific antibodies implicate basic fibroblast growth factor in normal wound repair. Lab Invest 1989, 61:571-575

31. Singer AJ, Clark RA: Cutaneous wound healing. N Engl J Med 1999 , 341:738-746

32. Werner S, Grose R: Regulation of wound healing by growth factors and cytokines. Physiol Rev 2003, 83:835-870

33. Grose R, Werner S: Wound-healing studies in transgenic and knockout mice. Mol Biotechnol 2004, 28:147-166

34. Gossen $\mathrm{M}$, Bujard $\mathrm{H}$ : Tight control of gene expression in mammalian cells by tetracycline-responsive promoters, Proc Natl Acad Sci USA: 1992, 89:5547-5551

35. Baron U, Bujard $\mathrm{H}$ : Tet repressor-based system for regulated gene expression in eukaryotic cells: principles and advances. Methods Enzymol 2000, 327:401-421

36. Liaudet-Coopman ED, Schulte AM, Cardillo M, Wellstein A: A tetracycline-responsive promoter system reveals the role of a secreted binding protein for FGFs during the early phase of tumor growth. Biochem Biophys Res Commun 1996, 229:930-937

37. McDonnell K, Bowden ET, Cabal-Manzano R, Hoxter B, Riegel AT, Wellstein A: Vascular leakage in chick embryos after expression of a secreted binding protein for fibroblast growth factors. Lab Invest 2005, 85:747-755

38. Stylianou DC, Auf der Maur A, Kodack DP, Henke RT, Hohn S Toretsky JA, Riegel AT, Wellstein A: Effect of single-chain antibody targeting of the ligand-binding domain of the anaplastic lymphoma kinase receptor. Oncogene 2009, 28:3296-3306

39. Wellstein A: Real-time, label-free monitoring of cells in cancer research. Science Webinar Series: "Advancing Cancer Research". USA: Science, AAAS Washington DC; 2010

40. Tsuboi R, Rifkin DB: Recombinant basic fibroblast growth factor stimulates wound healing in healing-impaired db/db mice. J Exp Med 1990, 172:245-251

41. Austyn JM, Gordon S: F4/80, a monoclonal antibody directed specifically against the mouse macrophage. Eur J Immunol 1981, 11:805815

42. Furth PA, St Onge L, Boger H, Gruss P, Gossen M, Kistner A, Bujard $\mathrm{H}$, Hennighausen L: Temporal control of gene expression in transgenic mice by a tetracycline-responsive promoter, Proc Natl Acad Sci USA: 1994, 91:9302-9306
43. Lewandoski M: Conditional control of gene expression in the mouse. Nat Rev Genet 2001, 2:743-755

44. Ray R, Cabal-Manzano R, Moser AR, Waldman T, Zipper LM, Aigner A, Byers SW, Riegel AT, Wellstein A: Up-regulation of fibroblast growth factor-binding protein, by beta-catenin during colon carcinogenesis. Cancer Res 2003, 63:8085-8089

45. Liu XH, Aigner A, Wellstein A, Ray PE: Up-regulation of a fibroblast growth factor binding protein in children with renal diseases. Kidney Int 2001, 59:1717-1728

46. Song QH, Klepeis VE, Nugent MA, Trinkaus-Randall V: TGF-beta1 regulates TGF-beta1 and FGF-2 mRNA expression during fibroblast wound healing. Mol Pathol 2002, 55:164-176

47. Rybarczyk BJ, Lawrence SO, Simpson-Haidaris PJ: Matrix-fibrinogen enhances wound closure by increasing both cell proliferation and migration. Blood 2003, 102:4035-4043

48. Liu J, Huang C, Zhan X: Src is required for cell migration and shape changes induced by fibroblast growth factor 1. Oncogene 1999 18:6700-6706

49. Cheon SS, Cheah AY, Turley S, Nadesan P, Poon R, Clevers H, Alman BA: beta-Catenin stabilization dysregulates mesenchymal cell proliferation, motility, and invasiveness and causes aggressive fibromatosis and hyperplastic cutaneous wounds, Proc Natl Acad Sci USA: 2002, 99:6973-6978

50. Mohammadi M, Froum S, Hamby JM, Schroeder MC, Panek RL, Lu GH, Eliseenkova AV, Green D, Schlessinger J, Hubbard SR: Crystal structure of an angiogenesis inhibitor bound to the FGF receptor tyrosine kinase domain. EMBO J 1998, 17:5896-5904

51. Aigner A, Butscheid M, Kunkel P, Krause E, Lamszus K, Wellstein A, Czubayko F: An FGF-binding protein (FGF-BP) exerts its biological function by parallel paracrine stimulation of tumor cell and endothelia cell proliferation through FGF-2 release. Int J Cancer 2001, 92:510517

52. Bikfalvi A, Klein S, Pintucci G, Rifkin DB: Biological roles of fibroblast growth factor-2. Endocr Rev 1997, 18:26-45

53. McGee GS, Davidson JM, Buckley A, Sommer A, Woodward SC, Aquino AM, Barbour R, Demetriou AA: Recombinant basic fibroblast growth factor accelerates wound healing. J Surg Res 1988, 45:145153

54. Heil M, Schaper W: Influence of mechanical, cellular, and molecular factors on collateral artery growth (arteriogenesis). Circ Res 2004, 95:449-458

55. O'Keefe EJ, Chiu ML, Payne RE, Jr.: Stimulation of growth of keratinocytes by basic fibroblast growth factor, J Invest Dermatol 1988 , 90:767-769

56. Park SG, Shin H, Shin YK, Lee Y, Choi EC, Park BJ, Kim S: The Novel Cytokine p43 Stimulates Dermal Fibroblast Proliferation and Wound Repair. Am J Pathol 2005, 166:387-398

57. Martin P: Wound healing-aiming for perfect skin regeneration. Science 1997, 276:75-81

58. Leibovich SJ, Ross R: The role of the macrophage in wound repair. A study with hydrocortisone and antimacrophage serum, Am J Pathol 1975, 78:71-100

59. Nagaoka T, Kaburagi Y, Hamaguchi Y, Hasegawa M, Takehara K, Steeber DA, Tedder TF, Sato S: Delayed wound healing in the absence of intercellular adhesion molecule-1 or L-selectin expression. Am J Pathol 2000, 157:237-247

60. Lin ZQ, Kondo T, Ishida Y, Takayasu T, Mukaida N: Essential involvement of interleukin- 6 in the skin wound-healing process as evidenced by delayed wound healing in interleukin-6-deficient mice. J Leukoc Biol 2003, 73:713-721

61. Gallucci RM, Simeonova PP, Matheson JM, Kommineni C, Guriel JL, Sugawara T, Luster MI: Impaired cutaneous wound healing in interleukin-6-deficient and immunosuppressed mice. FASEB J 2000, 14: 2525-2531

62. Gallucci RM, Sugawara T, Yucesoy B, Berryann K, Simeonova PP, Matheson JM, Luster MI: Interleukin-6 treatment augments cutaneous wound healing in immunosuppressed mice. J Interferon Cytokine Res 2001, 21:603-609

63. Napoli C, de Nigris F, Welch JS, Calara FB, Stuart RO, Glass CK, Palinski W: Maternal hypercholesterolemia during pregnancy promotes early atherogenesis in LDL receptor-deficient mice and alters aortic gene expression determined by microarray. Circulation 2002, 105:1360-1367 
64. Ray PE, Tassi E, Liu XH, Wellstein A: Role of fibroblast growth factor-binding protein in the pathogenesis of HIV-associated hemolytic uremic syndrome. Am J Physiol Regul Integr Comp Physiol 2006, 290:R105-R113

65. Tassi E, Walter S, Aigner A, Cabal-Manzano RH, Ray R, Reier PJ, Wellstein A: Effects on neurite outgrowth and cell survival of a secreted fibroblast growth factor binding protein upregulated during spinal cord injury. Am J Physiol Regul Integr Comp Physiol 2007, 293:R775-R783

66. Kagan BL, Henke RT, Cabal-Manzano R, Stoica GE, Nguyen Q, Wellstein A, Riegel AT: Complex regulation of the fibroblast growth factor-binding protein in MDA- MB-468 breast cancer cells by
CCAAT/enhancer-binding protein beta. Cancer Res 2003, 63 1696-1705

67. Dvorak HF: Tumors: wounds that do not heal. Similarities between tumor stroma generation and wound healing, N Engl J Med 1986, 315:1650-1659

68. Dvorak HF: Rous-Whipple Award Lecture. How tumors make bad blood vessels and stroma, Am J Pathol 2003, 162:1747-1757

69. Schäfer M, Werner S: Cancer as an overhealing wound: an old hypothesis revisited. Nat Rev Mol Cell Biol 2008, 9:628-638

70. Virchow RLK: Vierte Vorlesung: Aetiologie der neoplastischen Geschwülste. Berlin, August Hirschwald Verlag, 1863, pp 57-71 